\title{
SPATIAL ANALYSIS OF EARTHQUAKES IN BULGARIA AND NEIGHBORING AREAS
}

\begin{abstract}
Alexander N. Sadovski
Abstract: Statistical methods including Quadrat analysis, Cluster analysis, Descriptive statistics and Geographic Information Systems are used to study spatial distribution and to summarize data about earthquakes in Bulgaria and neighboring areas. Detection of areas with similar pattern of earthquakes occurrence is of interest for the Government and for general public. Seismic risk for NPP "Belene" is discussed.
\end{abstract}

Key words: Earthquakes, Spatial analysis, Statistical methods, Geographic Information Systems, NPP "Belene".

\section{INTRODUCTION}

The purpose of this article is study of the spatial distribution of earthquakes in Bulgaria and neighboring areas and to present statistical characteristics related to their magnitude. It will help for better understanding of the risk of such natural disaster (seismic hazard). Some perspectives on spatial differentiation could be considered: (a) interest in areal distribution; (b) interest in spatial structure; and (c) concern with the explanation of areal variation. Since spatial data are neither the outcome of controlled experiments, nor do they result from random samples, it is clear that beyond mapping and informal inference from patterns, specific spatial statistical methods are required.

Major earthquakes in our latitudes were in I, IX, XVI, XVII and XVIII century, information about which is available only in old historical writings. According to some sources, the most destructive earthquake in the country was with a magnitude about sixth to ninth degree on the Richter scale and its epicenter was near Sofia, the earthquake happened on 18 September 1858. Systematic observations of earthquakes began in Bulgaria in 1892, when was founded Seismological Service at the Central Meteorological station in Sofia [27].

Here is a list [27, 28] of strong earthquakes with magnitude greater than 5 from the early 20 th century to present:

- On March 31, 1901 - the area between the town of Shabla and cape Kaliakra with magnitude 7.2 on the Richter scale;

- On April 4, 1904 - the river Struma valley magnitude 7.8 on the Richter scale;

- On October 8, 1905 - the river Struma valley - magnitude 6.4 on the Richter scale;

- On January 10, 1908 - Gorna Oriahovitsa magnitude 7 on the Richter scale;

- On April 14, 1909 - Gorna Oriahovitsa magnitude 7 on the Richter scale;
- On June 14, 1913 - Gorna Oriahovitsa magnitude 7 on the Richter scale;

- On October 18, 1917 - Sofia - magnitude 5.3 on the Richter scale;

- On April 14, 1928 - Chirpan - magnitude 6.9 on the Richter scale;

- On 18 and 25 April, 1928 - Popovitsa and Galabovo /Plovdiv area/, earthquakes with magnitude 7.0 and 5.6 on the Richter scale;

- On March 17, 1942 - Razgrad - magnitude 7.0 on the Richter scale;

- On June 30, 1956 - Shabla - magnitude 5.5 on the Richter scale;

- On March 4, 1977 - Vrancea /Romania/ magnitude 7.2 on the Richter scale;

- On November 3, 1977 - Velingrad magnitude 5.3 on the Richter scale;

- On February 28, 1986 - Strajitsa magnitude 5.1 on the Richter scale;

- On December 7, 1986 - Popovo - magnitude 5.7 degrees on the Richter scale;

- On October 27, 2004 - about 430 km. northeast of Sofia, outside the country - magnitude 5.5 on the Richter scale;

- On May 22, 2012 - Pernik earthquake with a series of seismic tremors that begin with a magnitude of 5.6.

Territory of Bulgaria unconditionally should be assigned to dangerous earthquake zones on Earth [26]. Furthermore, the seismicity of the territory of neighboring countries, Greece, Turkey, the former Yugoslavia and Romania has a significant impact on the assessment of seismic hazard for the territory of Bulgaria (particularly a seismic impact on intermediate-focus earthquakes in the Vrancea region, Romania). The literature describes the following major zones on epicenters of earthquakes with impacts on the territory of Bulgaria [18, 29]:

1. Vrancea seismic zone (Romania);

2. Gorna Oriahovitsa seismic zone;

3. Shabla seismic zone; 
4. Provadiya seismic zone;

5. Negotinska Kraina and Timoc seismic zone (Serbia);

6. Sofia seismic zone;

7. Struma (Kresna) seismic zone;

8. Maritsa seismic zone;

9. Xanthi seismic zone (Greece);

10. Marmara Sea seismic zone (Turkey).

The nature of modern geodynamic processes in Bulgaria and neighboring areas can be outlined in a general way by the grouping of epicenters of earthquakes with magnitude $M \geq 4$. Data are from several sources $[2,4,20]$ and publications of Bulgarian authors [1]. Stands out is the high seismicity, some earthquakes with a magnitude of more than 7 , although not with high frequency of repetition.

\section{CONCEPT AND METHODS}

The concept, which is used in this study, is that of "randomness". If $\mathrm{N}$ points are located randomly in a planar region, then the probability distribution of this random spatial point pattern follows the Poisson law. An observed frequency distribution, which does not conform to the expected from a random point process, leads to rejection of the hypothesis of randomness in favor of the alternative - more regular or more clustered, than the random model.

The method applied for study spatial distribution of the earthquakes in Bulgaria and neighboring areas is called "Quadrat analysis" [3, 13, 14, 19]. In the quadrat method a planar study region is divided into a grid with cells of equal size, called "quadrats", and the number of points in each cell is counted. A regular point process generates a large number of quadrats containing only a single point, some empty quadrats and a very few quadrats with more than one point in them. Conversely, a clustered point process is expected to produce a very large number of empty quadrats, a few quadrats with one or two points, and several quadrats with many points in them.

Analyses have shown that the Poisson distribution

(1) $P_{1}(x)=\exp (-\lambda a) \frac{(\lambda a)^{x}}{x !},(\mathrm{x}=0,1,2, \ldots, \mathrm{n})$

corresponds to random spatial dispersion.

The Binomial distribution

(2) $P_{2}(x)=\sum_{x=0}^{n}\left(\begin{array}{l}n \\ r\end{array}\right) p^{x}(1-p)^{n-x}$

is connected with regular spatial pattern, and the Negative binomial distribution
(3) $P_{3}(x)=\sum_{x=1}^{n}\left(\begin{array}{l}k+x-1 \\ x\end{array}\right) p^{k}(1-p)^{x}$

corresponds to clustered spatial dispersion.

It is known that the following inequalities exist [9]:

Binomial distribution Variance $<$ Mean

Poisson distribution $\quad$ Variance $=$ Mean

Negative binomial distribution Variance $>$ Mean

They could give indication about the type of statistical distribution and corresponding point process.

If the hypotheses of randomness and regularity are rejected, that it is convenient to apply some method of cluster analysis. For our purposes we select the minimal dispersion method [21] and Canberra Metric, calculated from original data.

Statistical analysis of earthquakes aims to describe and summarize data about their magnitude, and to reveal natural groups (clusters) of theirs places. Data from 137 sources - places of earthquakes with magnitude $M \geq 4$ are object of the analysis. Such set of data is sufficient for reliable inferences and conclusions.

\section{SPATIAL DISTRIBUTION OF EARTHQUAKES}

A digitized map of Balkan area with scale 1:3 000000 is used as a base map [6]. The places of earthquakes with their longitude/latitude coordinates have been overlaid on this base map. The whole area is divided into a grid with cells of equal size (quadrats $1.0^{\circ}$ longitude by $1.0^{\circ}$ latitude) and the pattern is shown on Fig. 1.

The number of points in each cell on the territory of interest is counted and sample statistics are calculated. To make conclusion about the character of observed spatial point pattern, three statistical distributions are fitted to the data: Binomial, Poisson and Negative binomial distribution. Results are presented in Table 1.

Two statistical tests are applied: Chi-square goodness of fit test

(4)

$$
\chi_{v}^{2}=\sum_{i=1}^{k} \frac{\left(O_{i}-E_{i}\right)^{2}}{E_{i}}
$$

and variance-mean ratio test

$$
t^{*}=\frac{\frac{m_{2}}{m_{1}}-1}{\sqrt{\frac{2}{N-1}}}
$$




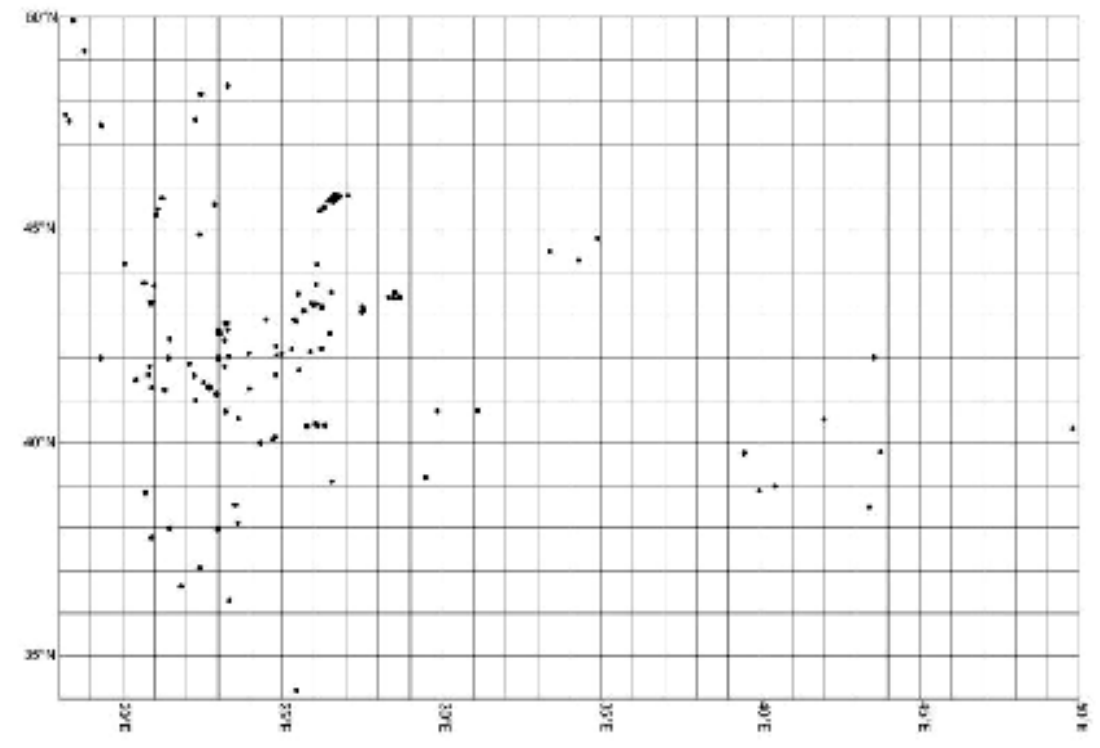

Fig. 1

Table 1. Observed and expected distributions of the earthquakes

\begin{tabular}{|c|c|c|c|c|}
\hline $\begin{array}{l}\text { No. of } \\
\text { points } \\
\text { per } \\
\text { cell } \\
\end{array}$ & $\begin{array}{l}\text { Observed } \\
\text { frequ- } \\
\text { ency }\end{array}$ & $\begin{array}{c}\mathrm{n}=137 \\
\mathrm{p}=0.00232\end{array}$ & $\begin{array}{c}\lambda \mathrm{a}= \\
0.31786\end{array}$ & $\begin{array}{l}\text { Neg. Binom. } \\
\begin{array}{l}\mathrm{w}=0.31786 \\
\mathrm{k}=0.07748\end{array}\end{array}$ \\
\hline $\begin{array}{c}0 \\
1 \\
2 \\
3 \\
4 \\
5 \\
6 \\
7 \\
8 \\
9 \\
10 \\
11 \\
12 \\
13 \\
14 \\
15 \\
16\end{array}$ & $\begin{array}{l}375 \\
30 \\
11 \\
5 \\
1 \\
6 \\
0 \\
0 \\
0 \\
0 \\
2 \\
0 \\
0 \\
0 \\
0 \\
0 \\
1\end{array}$ & $\begin{array}{c}313.53 \\
99.88 \\
15.79 \\
1.65 \\
0.13 \\
0.01 \\
0.00 \\
0.00 \\
0.00 \\
0.00 \\
0.00 \\
0.00 \\
0.00 \\
0.00 \\
0.00 \\
0.00 \\
0.00\end{array}$ & $\begin{array}{c}313.64 \\
99.69 \\
15.84 \\
1.68 \\
0.13 \\
0.01 \\
0.00 \\
0.00 \\
0.00 \\
0.00 \\
0.00 \\
0.00 \\
0.00 \\
0.00 \\
0.00 \\
0.00 \\
0.00\end{array}$ & $\begin{array}{c}379.87 \\
23.66 \\
10.25 \\
5.71 \\
3.53 \\
2.31 \\
1.57 \\
1.10 \\
0.78 \\
0.56 \\
0.41 \\
0.30 \\
0.23 \\
0.17 \\
0.13 \\
0.10 \\
0.00\end{array}$ \\
\hline $\mathrm{P}_{0.001}{ }^{. \chi^{2}}$ & $\begin{array}{c}- \\
- \\
- \\
- \\
\text { at } 1 \%=0.0785\end{array}$ & $\begin{array}{r}694.43 \\
15 \\
37.70 \\
\mathrm{p}<0.001 \\
0.7402\end{array}$ & $\begin{array}{r}694.43 \\
15 \\
37.70 \\
\mathrm{p}<0.001 \\
0.7400\end{array}$ & $\begin{array}{r}20.645 \\
15 \\
24.32 \\
\mathrm{p}<0.148 \\
0.9997\end{array}$ \\
\hline
\end{tabular}


where: $\mathrm{O}_{\mathrm{i}}$ are observed frequencies, $\mathrm{E}_{\mathrm{i}}$ are expected frequencies and $v$ - degrees of freedom; $\mathbf{m}_{1}$ is Mean, $\mathbf{m}_{2}$ is Variance and $\mathbf{N}$ - number of observations.

It is evident that values of $\chi^{2}$ for Binomial and Poisson distributions exceed the critical value from chi-square table (37.70), which lead to rejection of the null hypothesis of regularness and randomness of spatial pattern. Only $\chi^{2}$ value for Negative binomial distribution is less than the critical value and shows a clustered point process.

The results from variance-mean ratio test are:

$\mathbf{m}_{1}=0.31786, \mathbf{m}_{2}=1.62198, \mathbf{m}_{2} / \mathbf{m}_{1}=5.10273$,

$\mathbf{t}^{*}=65.5795, v=511, \mathrm{p}<0.001$,

which confirms that the observed spatial dispersion is significantly different from the random Poisson model.

The standard Kolmogorov-Smirnov test for comparing two frequency distributions can also be applied. The test statistic " $\mathrm{D}$ " is simply given by the largest difference (irrespective of sign) between observed cumulative frequency and expected cumulative frequency:

\section{$\mathrm{D}=\max$ [Cum Obser. Freq - Cum Expect. Freq]}

The critical value at the $1 \%$ level is 0.07851 . Observed frequencies differ significantly from the theoretical distributions, which confirms a clustered point process.

\section{SPATIAL \\ EARTHQUAKES} STRUCTURE

OF

The study is accomplished with help of statistical package STATISTICA, system for surfaces mapping SURFER and geographic information system (GIS) MapInfo.

Relationships between 137 places of earthquake are examined by the method of hierarchical agglomerative cluster analysis [7, 12, 16]. It is known that all combinatorial methods for such analysis have common equation

(6) $\mathrm{d}_{\mathrm{hk}}=\alpha_{\mathrm{i}} \mathrm{d}_{\mathrm{hi}}+\alpha_{\mathrm{j}} \mathrm{d}_{\mathrm{hj}}+\beta \mathrm{d}_{\mathrm{ij}}+\gamma\left|\mathrm{d}_{\mathrm{hi}}-\mathrm{d}_{\mathrm{hj}}\right|$,

where parameters $\alpha_{i}, \alpha_{j}, \beta$ and $\gamma$ determine method.

Here Ward's method is used [21], for which

(7)

$\alpha_{i}=\frac{n_{h}+n_{i}}{n_{h}+n_{k}} ; \alpha_{j}=\frac{n_{h}+n_{j}}{n_{h}+n_{k}} ; \beta=\frac{-n_{h}}{n_{h}+n_{k}} ; \gamma=0$.

This method minimizes within-group sum of squares and it is called method of the minimal dispersion.

For similarity measure so-called Canberra Metric is used
(8)

$$
D_{c}(a, b)=\sum_{j=1}^{m}\left|x_{a j}-x_{b j}\right| /\left|x_{a j}-x_{b j}\right|
$$

where $\mathrm{x}_{\mathrm{aj}}$ is value of variable $\mathrm{j}$ for object $\mathbf{a}, \mathrm{m}$ is total number of variables.

The application of Ward's method gives a dendrogram, presented on Fig. 2. Nine clusters are found and their members are listed in Table 2.

It is interesting to notice that cluster 1 includes earthquakes in Eastern Bulgaria. In cluster 2 are some places in middle part of Bulgaria, Eastern Greece and European part of Turkey. Cluster 3 consists of earthquakes in Western Bulgaria and Macedonia. In cluster 4 are all earthquakes in Romania, a few in Bulgaria and one in Moldavia. Cluster 5 covers places in Turkey and Ukraine of the Black Sea region. Cluster 6 consists of Central Greece only. In cluster 7 are earthquakes from Albania, Macedonia and Serbia. Cluster 8 covers places in Hungary, Slovakia and Western Romania. Cluster 9 presents Eastern Turkey and part of Caucasus region.

Separate contour maps, which are twodimensional representation of three-dimensional data from places of earthquakes, are produced with help of procedure "Kriging" [10, 11]. It is one of the most useful methods for generating regularly spaced arrays of $\mathbf{Z}$ values from irregularly spaced $\mathbf{X Y Z}$ data. The derived contour maps are overlaid on the intermediate map and could be easily interpreted [5, 17] (see Fig 3).

\section{DESCRIPTIVE STATISTICS OF EARTHQUAKES}

The main index selected for the study is magnitude of earthquakes on the Richter scale $(M \geq$ 4). Basic descriptive statistics for the characteristics of all 137 places of earthquakes are calculated, namely: mean, median, minimal and maximal values, standard deviation, skewness and kurtosis $[15,22]$. They are given in Table 3 .

\section{DISCUSSION ABOUT SEISMIC RISK FOR NPP "BELENE"}

The report of the Bulgarian Academy of Sciences from 1990 - NPP "Belene" Studies and Position of BAS" [23, 24] makes the following conclusion: "The possible maximum magnitude of earthquakes in the area of the site /fault line of the Danube river/ 5,5; node of Nikopol $/ 30 \mathrm{~km}$ west of it/ and Svishtov node $/ 15 \mathrm{~km}$ east of it/ is 6.0, and about $25 \mathrm{~km}$ southeast of it - 6.5. These data should be considered in determination of the seismic risk." 


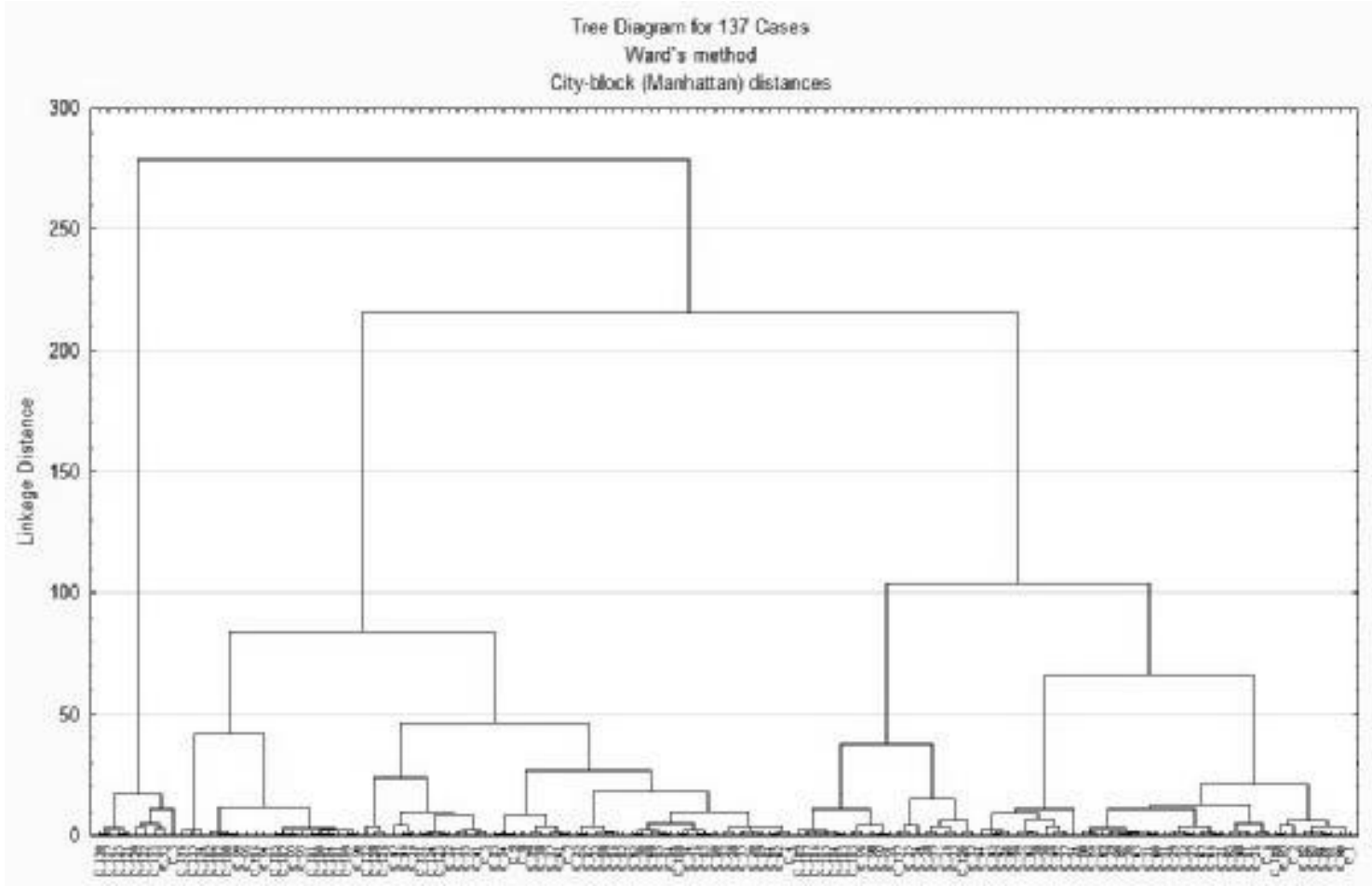

Fig. 2

Still following words: "... if a 7.2 magnitude learthquake "Vrancea"- 1977/ of NPP "Belene" is established intensity of seventh degree, then with a magnitude greater than 7.5 could be expected intensity exceeding eight degrees."

Follows citation of Soviet "Guidelines on location of nuclear stations" - 1987 and "Regulation about design of seismostable nuclear stations - NPAЭ D-006-87," according to which sites with engineering-geological conditions as those of NPP "Belene" are unfavorable to construction of nuclear power plants, in accordance with paragraph 2.3.1.3 of the same Guidelines in a zone of intensity for MP3, higher than the eighth degree, the placement of nuclear power plant is not allowed.

In his analysis of the future of nuclear energy and energy security of Bulgaria F. Dudin [25] states: "In this region studies have shown the danger of earthquakes at 7 - 8 degrees on the Richter scale on Bulgarian territory and more than 8 degrees in Romania with an average frequency once every 50 years (the last such was in 1977). Unfortunately 8 degrees is the maximum for the chosen building site can take as a design basis earthquake and in account of the enormous radiation risks must be envisaged reserve to 9 degrees for safe shutdown earthquake."
In the article by Investor.bg from 03/11/2013 "NPP Kozloduy and future NPP Belene could withstand an earthquake" [8] the chairman of the Nuclear Regulatory Agency Sergey Tzotchev says that "NPP Belene is designed with 40\% "reserve" for an earthquake, that when set parameters for ground acceleration of $0,24 \mathrm{~g}$, or 8 th grade on the scale of Medvedev the plant could sustain acceleration of $0,34 \mathrm{~g}$, or ninth degree in the same scale." It should be noted that the intensity of the earthquake I /by Medvedev/ to a location on the surface of the Earth depends on the magnitude of the earthquake M /by Richter/ at the centre and the distance to hypocenter the earthquake. An earthquake of 10 grade scale of Medvedev corresponds to a magnitude 8.0 on the Richter scale at a depth of 45 kilometers of the outbreak.

The peculiarity of the Vrancea earthquakes is the large focal depth. Pockets of the largest earthquakes are mainly located at a depth of 110 $150 \mathrm{~km}$. In connection with this, area of the destructive and tangible shock extends over large distances. With such a large magnitude and large focal depth Vrancea earthquake is felt by the population for a vast territory of Greece in the south to Finland in the north and from the European part of Russia in the east to the west of Germany [30]. 
In connection with the foregoing, the assessment of seismic risk for the planned and under construction objects in the south-western regions of the East-European platform must consider the impact of the earthquake or seismic potential of local seismic source zones and Vrancea.

Table 2. Clusters and their members

\begin{tabular}{|c|c|c|c|c|}
\hline Cluster 1 & \begin{tabular}{|l|} 
Cluster 2 \\
\end{tabular} & Cluster 3 & \begin{tabular}{|l|} 
Cluster 4 \\
\end{tabular} & \begin{tabular}{|l} 
Cluster 5 \\
\end{tabular} \\
\hline $\begin{array}{l}\text { Galabovo } \\
\text { Kaliakra } \\
\text { Kamen bryag } \\
\text { Kavarna } \\
\text { Kurdjali } \\
\text { Mirovo } \\
\text { Ovchi kladenec } \\
\text { Popovo } \\
\text { Popovo } \\
\text { Provadia } \\
\text { Radnevo } \\
\text { Ruse } \\
\text { Shabla } \\
\text { Strazhitsa } \\
\text { Triavna } \\
\text { Triavna } \\
\text { Varna } \\
\text { Varna } \\
\text { Varna } \\
\text { Yambol } \\
\text { Yambol } \\
\text { Budeni }\end{array}$ & $\begin{array}{l}\text { Chirpan } \\
\text { G. Oriahovica } \\
\text { G. Oriahovica } \\
\text { Popovitsa } \\
\text { Sofia } \\
\text { Struma } \\
\text { Alexandropoli } \\
\text { Kavala } \\
\text { Kavala } \\
\text { Kavala } \\
\text { Mitilini } \\
\text { Panorama } \\
\text { Canakkale } \\
\text { Canakkale } \\
\text { Gelibolu }\end{array}$ & $\begin{array}{l}\text { Cherna gora } \\
\text { KCM } \\
\text { Kralev dol } \\
\text { Pernik } \\
\text { Rila M. } \\
\text { Smolian } \\
\text { Sofia } \\
\text { Sofia } \\
\text { Sofia } \\
\text { Struma } \\
\text { Troian } \\
\text { Velingrad } \\
\text { Drama } \\
\text { Panorama } \\
\text { Basibos } \\
\text { Dink } \\
\text { Bashibos } \\
\text { Belotino } \\
\text { Gevgelija } \\
\text { Negotino } \\
\text { Nikolik } \\
\text { Novo Selo } \\
\text { Prsten } \\
\text { Sveti Nikole } \\
\text { Valandovo }\end{array}$ & $\begin{array}{l}\text { Balchik } \\
\text { Razgrad } \\
\text { Tirnovo } \\
\text { Kishinev } \\
\text { Braila } \\
\text { Buzau } \\
\text { Covasna } \\
\text { Covasna } \\
\text { Kovasna } \\
\text { Kovasna } \\
\text { Nehoiu } \\
\text { Nehoiu } \\
\text { Nehoiu } \\
\text { Vrancea } \\
\text { Vrancea } \\
\text { Vrancea } \\
\text { Vrancea } \\
\text { Vrancea } \\
\text { Vrancea } \\
\text { Nehoiu }\end{array}$ & $\begin{array}{l}\text { Duzce } \\
\text { Gediz } \\
\text { Golcuk } \\
\text { Crimea } \\
\text { Kherson } \\
\text { Sudak }\end{array}$ \\
\hline
\end{tabular}

\begin{tabular}{|l|l|l|l|}
\hline \multicolumn{1}{|c|}{ Cluster 6 } & \multicolumn{1}{|c|}{ Cluster 7 } & \multicolumn{1}{c|}{ Cluster 8 } & \multicolumn{1}{c|}{ Cluster 9 } \\
\hline Athens & Tirana & Karvina & Badamdar \\
Athens & Ulcinj & Beregdaroc & Surami \\
Chania & Bitola & Budapest & Bingol \\
Iraklion & Debar & Budapest & Bingol \\
Kalamata & Dolna Banjica & Gyor & Erzincan \\
Lefkada & Ohrid & Oroszlany & Erzincan \\
Loutrakion & Skopie & Pishkol & Karakose \\
Patras & Zajas & Hateg & Oltu \\
Sparti & Orsava & Timisoara & Van \\
Zakinthos & Gnjilane & Voiteg & \\
Zakinthos & Kopaonik & Vrsac & \\
& Kraljevo & Zilina & \\
& Kursumilja & Dolge & \\
& Mionica & & \\
& Novi Pazar & & \\
& Trstenik & & \\
\end{tabular}


Table 3. Descriptive statistics of earthquakes $(\mathrm{N}=137)$

\begin{tabular}{|l|rrrrrrr|}
\hline Variable & \multicolumn{1}{|c}{ Mean } & \multicolumn{1}{c}{ Median } & \multicolumn{1}{c}{ Min } & \multicolumn{1}{c}{ Max } & Std.Dev. & \multicolumn{1}{c|}{ Skew. } & \multicolumn{1}{c|}{ Kurt. } \\
\hline Longitude & 25.55 & 24.80 & 18.20 & 49.80 & 5.462 & 2.084 & 5.139 \\
Latitude & 42.62 & 42.59 & 34.20 & 49.91 & 2.741 & -0.031 & 0.336 \\
Magnitude & 5.64 & 5.50 & 4.00 & 8.00 & 1.061 & 0.225 & -1.085 \\
\hline
\end{tabular}

Our analysis shows that the estimated magnitude of an earthquake at the Belene site is approximate 7,5 on the Richter scale. Comparison of the Fig. 3 and Fig. 4 shows that the USGS - Bulgaria Seismic Hazard Map is not enough detailed and underestimates seismic hazard in the Northern Bulgaria. It is clear that despite all the safety measures in the construction, the selected construction site of NPP "Belene" does not provide reserve up to 9 degree seismic certainty [23, p 324].

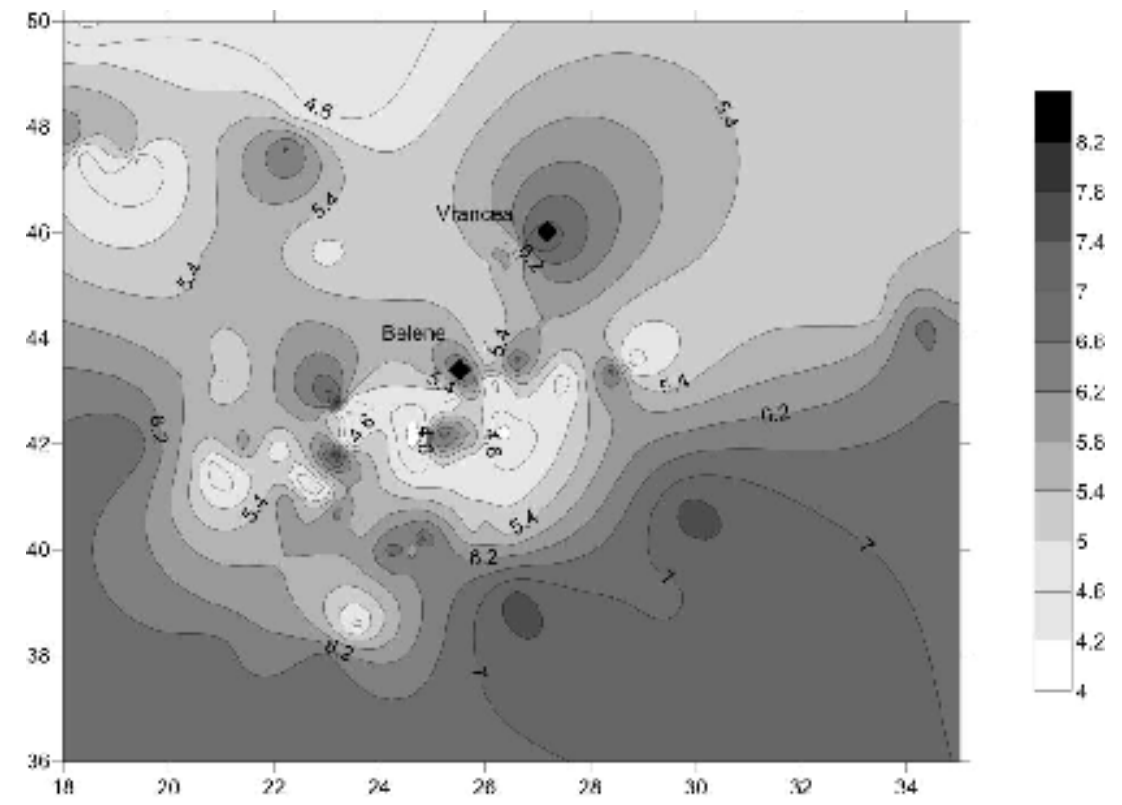

Fig. 3 Estimated magnitudes

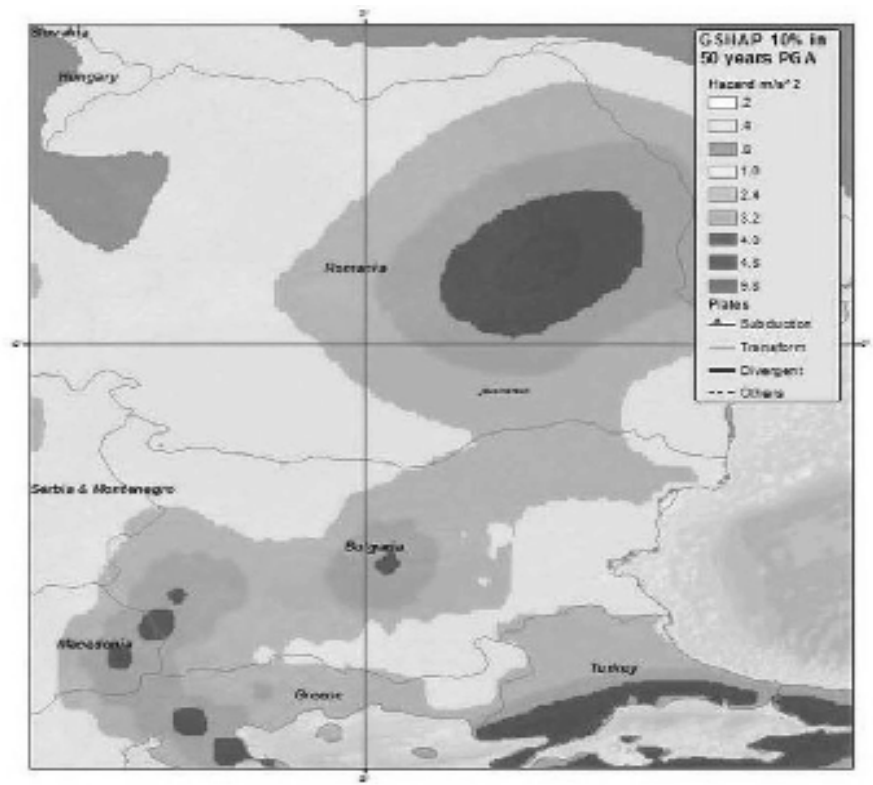

Fig. 4 From: USGS - Bulgaria Seismic Hazard Map 


\section{CONCLUSIONS}

Use of several statistical methods such as Quadrat analysis, Cluster analysis, Descriptive statistics and Geographic Information Systems has allowed revealing spatial distribution and spatial structure of earthquakes in Bulgaria and neighboring areas. The study rejects the hypothesis of random dispersion of earthquakes over the country's territory in favor of the alternative - more clustered, than the random model. Cluster analysis allocates all 137 places into 9 clusters with distinct properties. Tables 2 - 4 give bases for more profound interpretation.

The result of present study indicates needs for more detailed research of seismic risk for Bulgaria and neighboring areas. It confirms that the territory of Bulgaria unconditionally should be assigned to dangerous earthquake zones on Earth.

\section{REFERENCES}

1. Botev E. et al., 2003 - 2012. Data and analysis of the events recorded by NOTSSI. Bulgarian Geophysical Journal, BAS.

2. Compare Eastern Europe Earthquakes, 2013. National Geophysical Data Center (NGDC). http://earthquakes.findthedata.org/d/b/Eastern-

Europe.

3. Cressie N., Ch. Wikle, 2011. Statistics for Spatio-Temporal Data, John Wiley and Sons.

4. Earthquake Track, 2013. Worldwide Earthquake Stats. All Earthquake Data Courtesy USGS. http://earthquaketrack.com/.

5. ESRI, 2001. ArcGIS Geostatistical Analyst. ESRI White paper.

6. Google, 2013. Map data. www.balkanhotel.com map-of-balkans.

7. Gruijter J. J. de, 1977. Numerical classification of soils and its application in survey. Soil Survey Papers, No. 12. Wageningen.

8. Investor.bg, 2013. NPP Kozloduy and future NPP Belene could withstand an earthquake. http://www.investor.bg/ikonomika-ipolitika/332/a/aec-kozlodui-i-bydeshtata-aec-belenebiha-izdyrjali-pri-zemetresenie, $128375 /$.

9. Kendall M., A Stuart. 1958. The Advanced Theory of Statistics, Vol. I. Ch. Griffin, London.

10. Li J., A. D. Heap, 2008. A Review of Spatial Interpolation Methods for Environmental Scientists. Geoscience Australia.

11. Nelson Mandela Metropolitan University, 2013. Lectures: Spatial Interpolation. http://tutor.nmmu.ac.za/uniGISRegisteredArea/Mate rial/Module3/AdobeFiles/Section05.pdf
12. Peter A. Rogerson, G. Lee, I. Yamada, 2006. Technical Report: Statistical Methods for the Detection and Monitoring of Spatial Clusters.

13. Rogers A., 1974. Statistical analysis of spatial dispersion. Pion Ltd London.

14. Rogers A., N. G. Gomar, 2010. Statistical Inference in Quadrat Analysis. UC Berkeley, http://onlinelibrary.wiley.com/doi/10.1111/j.15384632.1969.tb00631.x/pdf.

15. Rogerson, P.A., 2001. Statistical Methods of Geography. Sage. London.

16. Rogerson, P. 2001a. A statistical method for the detection of geographic clustering. Geographical Analysis, 33: 215-27.

17. Sadovski L. A., A. N. Sadovski, 1998. Geographic information systems - Indispensable tool for Ecology. J. Balkan Ecology, vol. 1, No. 3, 9 - 15.

18. Shebalin N.V., G. Reisner, A. Drumea, J. Aptekman, V. Sholpo, N. Stepanenko, A. Zacharova, 1976. Earthquake origin zones and distribution of maximum expected seismic intensity for the Balkan region. Proc. Sem. on Seismic Zoning Maps, Skopje 1975, II, pp. 68-171.

19. Thomas R. W., 1977. An introduction to quadrat analysis. Concepts and techniques in modern Geography No. 12.

20. USGS, 2012. Bulgaria - Seismic Hazard Map.

http://earthquake.usgs.gov/earthquakes/world/bulgar ia/gshap.php.

21. Ward J. H. Jr., 1963. Hierarchical Grouping to optimize an Objective Function. Amer. Stat. Assoc. Journal, vol. 58, 236-244.

22. Wikle Ch. K., 2012. Statistics for SpatioTemporal Data. University of Missouri.

23. БАН, 1990. АЕЦ "Белене": Изследвания и становище на БАН, ред. П. Цветанов. Изд. БАН.

24. Доклад на БАН за проект "АЕЦ Белене", 1990 г., ред. ст. н. с. Пламен Цветанов, http://www.zelena-ikonomika.ekonetbg. org/01 upload/doc/02 library/ ban_belenereport1990_scanbczi_2011_ocr2. pdf.

25. Дудин Ф., 2013. Анализ на АЕЦ „Белене”, бъдещето на ядрената енергетика и енергийната сигурност на България. http://ebookbg.com/index.php?

option $=$ com docman\&task $=$ doc $\_$view\&gid $=$ $3945 \&$ Itemid $=61$.

26. Солаков Д., 2009. Сеизмично райониране на Република България, съобразено с изискванията на Еврокод 8 и изработване на карти за сеизмичното райониране с отчитане на 
сеизмичния хазарт върху територията на страната. БАН, Геофизичен Институт.

27. Тотков Н., 2012. История на земетресенията в България през XX век. http://ntotkov.blogspot.com/2012/12/blog-post.html.

28. Уикипедия, 2013. Земетресения в България. http://bg.wikipedia.org/wiki/.

29. Шанов Ст., 2006. Регионална сеизмичност

на Източната част на Централния Балкански полуостров. Курс по Сеизмотектоника. http://www.geology.bas.bg/lecture/seismo/seismotec tonics-lecture.pdf.

30. Шаров Н., А. Маловичко, Ю. Щукина (Ред.), 2007. Зелметрясения и микросеизмичность в задачах современной геодинамики ВосточноЕвропейской платформы - Книга 1, Землятресения. Карельский Научный Центр, Российская Академия Наук, Петрозаводск

\title{
ПРОСТРАНСТВЕН АНАЛИЗ НА ЗЕМЕТРЕСЕНИЯТА В БЪЛГАРИЯ И СЪСЕДНИТЕ ТЕРИТОРИИ
}

\author{
Александър Н. Садовски
}

Резюме: Статистически методи, включително Quadrat анализ, Клъстърен анализ, Дескриптивна статистика и Географски Информационни Системи се използват за изследване пространственото разпределение и да се обобщят данни за земетресенията в България и съседните области. Откриването на райони с подобна картина за поява на земетресения е от интерес за Правителството и за широката общественост. Дискутира се сеизмичният риск за АЕЦ "Белене".

Ключови думи: Земетресения, пространствен анализ, статистически методи, Географски информационни системи, АЕЦ "Белене"

Проф. Д-р Александър Н. Садовски

Академик на МАНЕ

Тел. 02-981-5586

e-mail: alexsad@hotmail.com
Prof. Dr. Alexander N. Sadovski

Academician of the IEAS

Phone: 02-981-5586

e-mail: alexsad@hotmail.com 